\title{
Identifying ESL Learners' Use of Multiple Resources in Vocabulary Learning
}

\author{
Shamini Pavadai1,2, Parilah M. Shah ${ }^{2}$ \\ ${ }^{1}$ SK Seri Sekamat, Kajang, Malaysia \\ ${ }^{2}$ Universiti Kebangsaan Malaysia, Bangi, Malaysia \\ Email: shaminip@live.com,drparila@gmail.com
}

How to cite this paper: Pavadai, S., \& Shah, P. M. (2019). Identifying ESL Learners' Use of Multiple Resources in Vocabulary Learning. Creative Education, 10, 3483-3490.

https://doi.org/10.4236/ce.2019.1013268

Received: November 5, 2019

Accepted: December 21, 2019

Published: December 24, 2019

Copyright (c) 2019 by author(s) and Scientific Research Publishing Inc. This work is licensed under the Creative Commons Attribution International License (CC BY 4.0).

http://creativecommons.org/licenses/by/4.0/

\begin{abstract}
Vocabulary knowledge plays a vital role in a successful language acquisition. It is essential and a fundamental element in language learning since it is considered the basis of any ESL learners. Students face tremendous difficulties in learning English vocabulary and show an aversion towards learning vocabulary. The present work investigated the use of multiple resources in learning vocabulary. A survey was carried out upon thirty Year 6 pupils of a primary school in Selangor. The instrument used in this research was a questionnaire to collect quantitative data. The findings showed that learners used a variety of resources in acquiring vocabulary in the four major skills. The finding also revealed that learners are more open to other resources outside the classroom. The usage of new technology enhances their vocabulary learning and they do not rely solely on teachers.
\end{abstract}

\section{Keywords}

Vocabulary, Vocabulary Learning Strategy, Resources, English as Second Language

\section{Introduction}

Vocabulary acquisition plays an important role in mastering a language. It is important for learners to have sufficient vocabulary to perform well in all aspects of language. ESL students face great problems with learning English vocabulary especially in listening, speaking, reading and writing. The inability to master vocabulary falls short as they have limited knowledge of vocabulary. According to Siyanova (2016), words learned from classroom instruction are limited due to lack of second language input.

One of the most important factors which influence the learning of vocabulary 
is the resources used by the learners. Learning strategies are critically important as vocabulary learning failed to take place as learners do not know how to master it. Once the right strategies are identified, lesson will be more successful (Rubin, 1987). The awareness of the students' learning can enhance language learning. Thus, this study is carried out to investigate the multiple resources used by the students in vocabulary learning in all of the four major skills.

\section{Literature Review}

\subsection{Vocabulary Learning Strategy}

Strategies are communicative procedures that learners use in order to learn and use language. It also involves mental in learning process (Nunan 1988). Oxford (2003) in more specifically stated that learning strategies are tools for active, self-directed involvement, which is essential for developing communicative competence. He also stressed that the purpose of language learning strategies taken by learners is to make a learning process easier, more fluent, more enjoyable, more self-directed, self-explanatory instruction and more transferable to new experience situations.

The development of the strategies is also on the basis that language learners need to be helped to improve the way they go about learning vocabulary and the ability to develop their own vocabulary learning strategies would become a powerful approach in vocabulary acquisition (Cunningsworth in Ali \& Kalajahi, 2012).

Learners need to be given the independence to try to improve themselves without fully depending on their teacher as there is no best method or teacher in learning vocabulary (Griffiths, 2003). Vocabulary learning strategies are helpful in moulding students in taking control of their own learning and improve their responsibility for their studies. This is supported by Ranalli (2003), that independence in vocabulary also helps in psychological condition of the learners to recall words more effectively since they decide what to learn by themselves.

However, learners might not be able to implement vocabulary learning strategies on their own and they should be trained and encouraged to use and to acquire new vocabularies by themselves (Cameron, 2001; Schmitt, 2000). This is supported by Ranalli (2003) who advocates that a good knowledge of the strategies and the ability to apply them in appropriate situations will considerably help students simplify.

\subsection{Classification of Vocabulary Learning Strategy}

Oxford (1990) classified VLS in two major categories, which are direct and indirect strategies. Direct strategies consist of cognitive, memory and compensation while indirect strategies consist of affective, metacognitive and social. Gu and Johnson (1996) on the other hand, focused on itemized VLS into 4 strategies which consists of cognitive, metacognitive, memory and activation strategies. According to him, this strategy is more realistic as a learner cannot depend on 
only one strategy to learn.

As for Schmitt (1997), he proposed a strategy which consists of strategy for discovery of meaning of the new words and the followed by the process of consolidation after discovery. His strategy is a combination of the direct and indirect strategy found in Oxford (1990) and O'Malley and Chamot (1990).

Seyyed Ali \& Akram (2015) in this study revealed that learners use different resources and reference material to learning English vocabulary. They not only use printed materials to learn but also take advantage of advances in technology in our increasingly multimedia world to expand their English vocabulary.

Gebremedhin Ghidey Kidane (2016) in this study, revealed that students learn through dictionary, guessing from context and ask for assistants from their friends. They rarely ask their teachers, keep vocabulary books or use English media.

Zhihong Bai (2018) carried out a study on learning strategies used by second grade non English major students in a university. The findings from the study revealed each method has advantage and disadvantages. Hence, there is a need to do further research on the resources use by learners as each learner is different individually.

Finally, a more recent study done by Aravind B. R \& Rajasekaran V (2018) was carried out to identify the most and frequent strategies used in vocabulary learning. The finding showed the popular strategies employed are using new words in the sentence, taking notes in the class, studying or spelling of words, spoken repetition and usage of dictionary. English language media is frequently used in learning and media such as songs video and newscast are of preference. Other methods, such as flash cards, analysing of parts of speech are not preferred.

From the discussion there seems to be mutual preferences for more than one strategy used in acquiring certain skill of a language and the need to use various vocabulary learning. Thus, there is a need to find out the multiple resources used by students in vocabulary learning as it consists of students are individually different in concepts, attitudes, age, and motivation. This can affect the students on choosing different resources in vocabulary learning.

\section{Methodology}

A descriptive survey method was employed on the ground to identify the resources used in vocabulary learning. The study was administered through a questionnaire to a total of 30 Year 6 pupils from SK Seri Sekamat, Kajang. It is a semi urban school located in the district Hulu Langat, Kajang. The samples consist of 15 males and 15 females. A simple random sampling technique is used to randomly select the samples. This study was conducted by administering a questionnaire to the samples. The questionnaire was adapted from Schmitt (1997). The first section of the questionnaire was the demography of the students. The questionnaire was divided into 4 parts. Each part consists of 5 items to the various language learning skills such as listening, speaking, reading and writing. 
responses to the statements. The five point Likert scale used in the study was 1-Never 2-Rarely 3-Sometimes 4-Often 5-Always. The findings from the study were analyzed using percentage count and were presented in the form of tables. Finally, based on the findings, conclusion and recommendation were given.

\section{Findings and Discussion}

Table 1, showed the different resources students use to learn new words. From the four statements on listening as in item 1, 36.7\%, 33.3\%, 13.3\% of the students replied often, sometimes and always respectively. However, $3.3 \%$ and $13.3 \%$ replied never and rarely respectively. This shows that, most students prefer to take down notes used by their teacher. As for item 2, 63.3\%, 26.7\% if students replied they rarely and sometimes respectively learn word with when in conversation with their friends. Only $10 \%$ replied often regarding learning words from friends. This shows students do not depend on their peers while using the language. As for item 3,40\%,33.3\% replied sometimes and often respectively to learning words by listening to lessons in class while $3 \%$ and $5 \%$ of the students said that they rarely and always. This shows that students prefer to learn by listening to lessons in class. This shows the students constantly rely on their teachers. As for item $4,60 \%$, and $23 \%$ of the students always and often use media in learning words through listening while $3.3 \%$ and $13.3 \%$ replied rarely and sometimes to usage of media. From this response, it can be inferred that majority of the students use media to learn new words in listening which is in line with Seyyed Ali \& Akram (2015).

Based on Table 2, from the 2 statements on speaking as in item 1, 46.7\% and $43.3 \%$, of the students replied rarely and sometimes respectively regarding learning new words while speaking with their other friends. The rest $10 \%$ of the

Table 1. Learning words through listening.

\begin{tabular}{|c|c|c|c|c|c|c|c|}
\hline No & Item & Never & Rarely & Sometimes & Often & Always & Mean \\
\hline 1 & $\begin{array}{l}\text { I note down unknown words } \\
\text { used by my teacher to learn later }\end{array}$ & $\begin{array}{c}1 \\
(3.3 \%)\end{array}$ & $\begin{array}{c}4 \\
(13.3 \%)\end{array}$ & $\begin{array}{c}10 \\
(33.3 \%)\end{array}$ & $\begin{array}{c}11 \\
(36.7 \%)\end{array}$ & $\begin{array}{c}4 \\
(13.3 \%)\end{array}$ & 3.43 \\
\hline 2 & $\begin{array}{l}\text { I learn words when my friends } \\
\text { use them }\end{array}$ & $\begin{array}{c}0 \\
(0 \%)\end{array}$ & $\begin{array}{c}19 \\
(63.3 \%)\end{array}$ & $\begin{array}{c}8 \\
(26.7 \%)\end{array}$ & $\begin{array}{c}3 \\
(10 \%)\end{array}$ & $\begin{array}{c}0 \\
(0 \%)\end{array}$ & 2.47 \\
\hline 3 & $\begin{array}{l}\text { I learn words by listening to } \\
\text { lessons in class }\end{array}$ & $\begin{array}{c}0 \\
(0 \%)\end{array}$ & $\begin{array}{c}3 \\
(10 \%)\end{array}$ & $\begin{array}{c}12 \\
(40 \%)\end{array}$ & $\begin{array}{c}10 \\
(33.3 \%)\end{array}$ & $\begin{array}{c}5 \\
(16.7 \%)\end{array}$ & 3.57 \\
\hline 4 & $\begin{array}{l}\text { I use media like songs, movies } \\
\text { and newspapers }\end{array}$ & $\begin{array}{c}0 \\
(0 \%)\end{array}$ & $\begin{array}{c}1 \\
(3.3 \%)\end{array}$ & $\begin{array}{c}4 \\
(13.3 \%)\end{array}$ & $\begin{array}{c}7 \\
(23.3 \%)\end{array}$ & $\begin{array}{c}18 \\
(60 \%)\end{array}$ & 4.40 \\
\hline
\end{tabular}

Table 2. Learning words through speaking.

\begin{tabular}{llcccccc}
\hline No & Item & Never & Rarely & Sometimes & Often & Always & Mean \\
\hline 1 & $\begin{array}{l}\text { I speak with other } \\
\text { friends }\end{array}$ & 0 & 13 & 14 & 3 & 0 & 2.67 \\
2 & $\begin{array}{l}\text { I ask my teacher for } \\
\text { translation }\end{array}$ & $\begin{array}{c}1 \\
(3.3 \%)\end{array}$ & $\begin{array}{c}10 \\
(33.3 \%)\end{array}$ & $\begin{array}{c}(46.3 \%) \\
(26.7 \%)\end{array}$ & $\begin{array}{c}(26.7 \%) \\
8\end{array}$ & $\begin{array}{c}(10 \%) \\
(10 \%)\end{array}$ & 3.07 \\
\hline
\end{tabular}


students said that they often speak to their friends to learn new words. This shows that students majority of the students are not in favor of learning new words by speaking to their friends. On the other hand, based on item 2, 33.3\% of the students rarely ask their teacher for translation in speaking while $26.7 \%, 10 \%$ and $3.3 \%$ replied sometimes, always and never respectively to seeking their teacher's aid. This indicates that they make effort to use the vocabulary by speaking to their friends and not finding the easy way out by asking their teacher.

On the aspect of item 1 of reading (Table 3), it is obvious that 50\% and 30\% of students always and often use media like songs, movies and newspapers. The rest $16.7 \%$ and $3.3 \%$ of the students replied sometimes and rarely respectively to usage of media. This shows that students prefer sources out of the classroom to enhance their vocabulary learning. As for item 2, 43.3\% and 33.3\% of the students always and often use the dictionary to find meaning of words. This is followed by $16.7 \%$ and $6.7 \%$ who responded sometimes and rarely respectively. It indicated that, students still use the dictionary as their source in learning vocabulary through reading. Although it is the traditional approach, students rely on dictionaries to look up for meaning of words. This supports the research of Gebremedhin Regarding item 3, 46.7\% and 30\% of the students use mobile phone, laptop and internet and their source in assisting them in vocabulary learning through reading. The rest $16.7 \%$ and $6.7 \%$ responded sometimes and rarely respectively to this item. Thus, it can be said that majority of students frequently use their gadgets and technology to help the in reading. Along with these in item $4,50 \%$ and $26 \%$ of students responded that they sometimes and often guess meaning from the context. The rest $13.3 \%$ and $10 \%$ said that they rarely and always guess meaning from the text read. Based on these, it is revealed that, the usage of mobile phone, lap top and internet to find meaning of new words is the highest of all reading inputs meanwhile the second highest is the usage of dictionary. Students still rely on bilingual dictionaries to find meaning of words.

Based on Table 4, as for item 1 in writing, $40 \%$ and $36.7 \%$ and $20 \%$ students responded often, always and sometimes respectively in learning new words through their writing exercises in class while 3.3\% rarely depend on their writing task in class. Based on item 2, 36.7\% and $26.7 \%$ of students responded sometimes

Table 3. Learning words through reading.

\begin{tabular}{|c|c|c|c|c|c|c|c|}
\hline No & Item & Never & Rarely & Sometimes & Often & Always & Mean \\
\hline 1 & $\begin{array}{l}\text { I use media like songs, movies } \\
\text { and newspapers }\end{array}$ & $\begin{array}{c}0 \\
(0 \%)\end{array}$ & $\begin{array}{c}1 \\
(3.3 \%)\end{array}$ & $\begin{array}{c}5 \\
(16.7 \%)\end{array}$ & $\begin{array}{c}9 \\
(30 \%)\end{array}$ & $\begin{array}{c}15 \\
(50 \%)\end{array}$ & 4.27 \\
\hline 2 & $\begin{array}{l}\text { I use a dictionary to find } \\
\text { meaning of new words }\end{array}$ & $\begin{array}{c}0 \\
(0 \%)\end{array}$ & $\begin{array}{c}2 \\
(6.7 \%)\end{array}$ & $\begin{array}{c}5 \\
(16.7 \%)\end{array}$ & $\begin{array}{c}10 \\
(33.3 \%)\end{array}$ & $\begin{array}{c}13 \\
(43.3 \%)\end{array}$ & 4.13 \\
\hline 3 & $\begin{array}{l}\text { I use mobile phone, laptop and } \\
\text { internet to find meaning of } \\
\text { new words. }\end{array}$ & $\begin{array}{c}0 \\
(0 \%)\end{array}$ & $\begin{array}{c}2 \\
(6.7 \%)\end{array}$ & $\begin{array}{c}5 \\
(16.7 \%)\end{array}$ & $\begin{array}{c}9 \\
(30 \%)\end{array}$ & $\begin{array}{c}14 \\
(46.7 \%)\end{array}$ & 4.17 \\
\hline 4 & $\begin{array}{l}\text { I guess the meaning from the } \\
\text { context }\end{array}$ & $\begin{array}{c}0 \\
(0 \%)\end{array}$ & $\begin{array}{c}4 \\
(13.3 \%)\end{array}$ & $\begin{array}{c}15 \\
(50 \%)\end{array}$ & $\begin{array}{c}8 \\
(26.7 \%)\end{array}$ & $\begin{array}{c}3 \\
(10 \%)\end{array}$ & 3.33 \\
\hline
\end{tabular}


Table 4. Learning words through writing.

\begin{tabular}{|c|c|c|c|c|c|c|c|}
\hline No & Item & Never & Rarely & Sometimes & Often & Always & Mean \\
\hline 1 & $\begin{array}{l}\text { I learn writing through my } \\
\text { writing exercises in class }\end{array}$ & $\begin{array}{c}0 \\
(0 \%)\end{array}$ & $\begin{array}{c}1 \\
(3.3 \%)\end{array}$ & $\begin{array}{c}6 \\
(20 \%)\end{array}$ & $\begin{array}{c}12 \\
(40 \%)\end{array}$ & $\begin{array}{c}11 \\
(36.7 \%)\end{array}$ & 4.10 \\
\hline 2 & $\begin{array}{l}\text { I learn new words when I send } \\
\text { or receive SMS/WhatsApp }\end{array}$ & $\begin{array}{c}3 \\
(10 \%)\end{array}$ & $\begin{array}{c}8 \\
(26.7 \%)\end{array}$ & $\begin{array}{c}11 \\
(36.7 \%)\end{array}$ & $\begin{array}{c}8 \\
(26.7 \%)\end{array}$ & $\begin{array}{c}0 \\
(0 \%)\end{array}$ & 2.80 \\
\hline 3 & $\begin{array}{l}\text { I learn new words when I chat } \\
\text { online. }\end{array}$ & $\begin{array}{c}1 \\
(3.3 \%)\end{array}$ & $\begin{array}{c}7 \\
(23.3 \%)\end{array}$ & $\begin{array}{c}17 \\
(56.7 \%)\end{array}$ & $\begin{array}{c}5 \\
(16.7 \%)\end{array}$ & $\begin{array}{c}0 \\
(0 \%)\end{array}$ & 2.87 \\
\hline 4 & $\begin{array}{l}\text { I learn new words when I write } \\
\text { or receive e mails }\end{array}$ & $\begin{array}{c}6 \\
(20 \%)\end{array}$ & $\begin{array}{c}10 \\
(33.3 \%)\end{array}$ & $\begin{array}{c}11 \\
(36.7 \%)\end{array}$ & $\begin{array}{c}3 \\
(10 \%)\end{array}$ & $\begin{array}{c}0 \\
(0 \%)\end{array}$ & 2.37 \\
\hline
\end{tabular}

and respectively on learning new words by the usage of SMS and WhatsApp while $26.7 \%$ and $10 \%$ replied often, rarely and never respectively. This shows that majority of the students use their gadgets and hand phone as a resource in assisting them in writing. On the other hand, item 3 , showed mixed response on the chatting on line to learn writing. $56.7 \%$ of the students sometimes use these facilities while $23.3 \%, 16.7 \%$ and $3.3 \%$ responded rarely, often and never to using the chat app to learn vocabulary. This shows students preference varied on the type of technology used in learning. In item $4,36.7 \%$ and $33.3 \%$ of the students replied sometimes and rarely respectively on learning words through emails while $20 \%$ and $10 \%$ of the students never and often use the email. This show email is not one of their favorite resources in learning vocabulary. Here, it shows that students are aware of the new resources to learn vocabulary in their writing skill instead of the traditional way. Thus, it is revealed that the linguistic inputs through technology and social situations influence students' choice of resources.

\section{Conclusion}

The descriptive analysis revealed multiple resources used by learners to learn new vocabulary. Some strategies were used more than others. From the finding, it is revealed that learners do not rely on teachers solely. Students preferred to listen to friends and use full advantage of media, such as mobile phone, laptops, internet and SMS as sources to learn words. Students learn through socializing and this helps them in their listening and speaking skills. This is due to the reason, students feel safe and feel free to use the language with their friends whereby trial and error in using the language are common. In addition, students are more open to other resources outside the classroom, such as new and latest technology such as mobile phone, internet and laptop. The advance of technology is gradually influencing students' learning and moving away from traditional approach of learning. From the findings, several implications can be drawn of the study for teachers, students and policy makers. Teachers need to be aware of preferred multiple resources used by students. It is indeed essential for teachers as by understanding students' preferred resources; they can plan more meaningful and effective lessons and subsequently use current teaching trends in vocabulary learning to keep abreast in current teaching resources. Policy makers 
need to take action and consider continuous training approaches and resources available provided to teachers on regular basis. This needs to be implemented so as teachers can improve their teaching and expose more current resources to students. Based on this study, students need o to be aware of various resources available apart from depending on the traditional resources of learning vocabulary. Further research can be carried out on the influence of students' gender and personality characteristics to vocabulary learning.

\section{Conflicts of Interest}

The authors declare no conflicts of interest regarding the publication of this paper.

\section{References}

Ali, S., \& Kalajahi, R. (2012). Vocabulary Learning Strategies and Vocabulary Size of ELT Students at EMU in Northern Cyprus. English Language Teaching, 5, 138-149. https://doi.org/10.5539/elt.v5n4p138

Aravind, B. R., \& Rajasekaran, V. (2018). A Study on Vocabulary Learning Strategies Research Scholars. The International Journal of Research in Teacher Education, 9, 16-25.

Bai, Z. H. (2018). An Analysis of English Vocabulary Learning Strategies. Journal of Teaching and Research, 9, 853-859. https://doi.org/10.17507/jltr.0904.24

Cameron, L (2001). Teaching Languages to Younger Learners. Cambridge: Cambridge University Press. https://doi.org/10.1017/CBO9780511733109

Griffiths, C. (2003). Language Learning Strategy Use and Proficiency: The Relationship between Patterns of Reported Language Learning Strategy (LLS) Use by Speakers of Other Languages (SOL) and Proficiency with Implications for the Teaching/Learning Situation. Doctoral Thesis, Auckland: University of Auckland. http://researchspace.auckland.ac.nz

Gu, Y. Q., \& Johnson, R. K. (1996). Vocabulary Learning Strategies and Language Learning Outcomes. Language Learning, 46, 643-679. https://doi.org/10.1111/j.1467-1770.1996.tb01355.x

Kidane, G. G. (2016) Assessing Students' Vocabulary Learning Perception and Strategy Use in Particular Reference to EFL Students of Adigrat University. International Journal of Science and Research, 7, 1701-1706.

Nunan, D. (1988). The Learner-Centered Curriculum. Cambridge: Cambridge University Press. https://doi.org/10.1017/CBO9781139524506

O’Malley, J. M., \& Chamot, A. U. (1990). Learning Strategies in Second Language Acquisition. New York: Cambridge University Press.

https://doi.org/10.1017/CBO9781139524490

Oxford, R. (1990). Language Learning Strategies: What Every Teacher Should Know. New York: Newbury House.

Oxford, R. (2003). Learning Styles \& Strategies. GALA.

Ranalli, J. M. (2003). The Treatment of Key Vocabulary Learning Strategies in Current ELT Coursebooks. Doctoral Thesis, Birmingham, UK: University of Birmingham. https://www.researchgate.net/publication/237796163

Rubin, J. (1987). Learner Strategies: Theoretical Assumptions, Research History and Typology. In A. Wenden, \& J. Rubin (Eds.), Learner Strategies in Language Learning (pp. 
15-30). Hertfordshire, UK: Prentice Hall International Ltd.

Schmitt, N. (1997). Vocabulary Learning Strategies. In N. Schmitt, \& M. McCarthy (Eds.), Vocabulary: Description, Acquisition, and Pedagogy (pp. 199-227). Cambridge: Cambridge University Press.

Schmitt, N. (2000). Vocabulary in Language Teaching. Cambridge, UK: Cambridge University.

Seyyed Ali, O. N., \& Akram, M. (2015). Vocabulary Learning Strategies from the Bottom-up: A Grounded Theory. The Reading Matrix: An International Online Journal, 15, 235-251.

Siyanova-Chanturia, A. (2016). Teaching Vocabulary in the EFL. 